\title{
Research on The Management of Municipal Solid Waste in Harbin City
}

\author{
Linlin Xuan \\ College of Public administration, \\ JILIN University \\ Changchun, China \\ 911076878@qq.com.
}

\author{
Min Ling \\ College of Finance and Public Administration Harbin \\ University of Commerce \\ Harbin, China \\ 673276972@qq.com.
}

\begin{abstract}
There are many problems in China's municipal solid waste management. The continuous growing urbanization in China is testing the current functions and management systems of the cities'. In this paper, the main purpose is to study this problem and propose some correct solutions This article makes studies on the occurred problems when the City of Harbin deals with its urban domestic waste management and makes systematic researches on the current situation as well as the causes of the urban domestic waste management in Harbin city. At the same time, this article also proposes legislative guidance of urban waste management, establishing a new management system and a pluralist invested system of municipal soil waste project. This paper relocate government's role of city government management, build new urban management pattern in China to provide theoretical support and policy suggestions.
\end{abstract}

Keywords-Public management; Municipal soil waste; City of Harbin

\section{INTRODUCTION}

After the reform and opening up, with China's market in full swing and international cooperation's further extension, the city's economic development level and influence have been growing up. At the same time, China's urbanization process is accelerating, the urbanization level has increased from $17.92 \%$ in 1978 to $51.27 \%$ in 2011, and is expected to reach $60 \%$ in 2020 . Population and economic activities is rapidly concentrating in urban areas. To some degree, it promotes the city's economic and social development, however, the problem it caused tests the existing urban functions and management system. The urban management mode and the system arrangement of urban interests subject put forward new demands.

Municipal Solid Waste (MSW), refers to in daily life in the city solid waste generated in service activities, and regarded as urban house refuse under laws and administrative rules and regulations of the solid waste. Harbin's rapid economic development and people life level unceasing enhancement, life garbage output also increased rapidly. Harbin city urbanization level from $27.8 \%$ in 1978 to $47.6 \%$ in 2010 , which began in 2000 , the annual average of $1 \%$, the urbanization in Harbin a total population of 9.9202 million people in 2010, the urban population to $47.6 \%$ of the total population. With the speeding up of urbanization, the garbage output of explosive growth, urban cleaning the garbage amount was 1.41 million tons in 2009.

\section{SITUATION OF HARBIN CITY's MUNICIPAL SOLID WASTE MANAGEMENT}

China's municipal solid waste management used to be called "environmental health management" conventionally. Before 1979, the management of municipal solid waste is under the charge of the Ministry of Health. , whose main responsibility is to ensure the city's clean and healthy. Concretely, it is responsible for road sweeping, garbage collection and transportation, excrement clear cut and transportation. From 1979, it is under the charge of urban construction department. Harbin municipal solid waste's service scope, pickup ability and processing capacity have been improving. During 2000-2010 in Harbin, the government invested sanitation machinery vehicles has increased to 843 at the end of 2010. In the past 10 years, there is no obvious change in the living garbage in the workload and cleaning area. Garbage container and the number of dump has not obviously increasing, it still in the same level and the number with 2000.

\section{A. Situation of Living Garbage in Harbin}

Harbin's daily waste is on an average of 3300 tons, There are five garbage harmless treatment plants in Harbin, of which are four in the main city zone, which are invested, constructed and operated by enterprise and to dispose the city garbage. Harbin hazard-free treatment rate of household garbage will increase to more than $90 \%$.As we can see from the composition of living garbage in Harbin, perishable organic material is a major component in Harbin's city living garbage, accounting for $76.45 \%$ of the waste weight. It also contains paper, plastic, glass, cloth, metal and wood in turn.

The basic process of disposing municipal solid waste is collection - transportation - process. At present, Harbin's city garbage collection mainly adopts the 
method of hybrid mobile phones - bag bag. According to the basic proximity principle, Harbin urban living garbage is sent to landfill for landfill or incineration, and the scale of processing is 1690 tons/day.

There are five garbage harmless treatment plants in Harbin, of which are four in the main city disposing the city garbage, those are invested and constructed and operated by enterprise and .They are mainly responsible for the main city living garbage treatment. Four daily harmless landfill are designed garbage processing capacity of 2900 tons.

But there are also many problems, such as the low garbage treatment rate. In Harbin, there has about 3300 tons of garbage a day on average to deal with. But currently living garbage processing capacity is only 1700 tons/day, which means that 1600 tons of waste every day has to adopt the the simple way to backward piled, and it cause seriously secondary pollution. With living garbage harmless treatment rapid urban's development, the system of garbage disposal has become elbow problems; Garbage transit facilities arebehinghand; Transport equipment is given priority to with the compression, high cost and low efficiency.

\section{B. Harbin Municipal Solid Waste Management Situation}

In recent years, Harbin municipal waste issues related regulations have carried out, but its management system is still the traditional planning model.

1) Management organization setting: The Harbin City Authority is an functional organization of the Harbin municipal government, which is responsible for city environment and health. Management Office's main functions of City's Environmental Sanitation are to supervise, inspect, guide and coordinate the work of the city appearance and environmental sanitation, and it is responsible for the city's garbage disposal and plant management.

2) Basic management laws and regulations system: The legal system of waste management of Harbin's city life consists of laws, administrative regulations, department regulations, local regulations, government rules and normative documents. From table 1 we can see that the management regulations on living garbage in Harbin city formulated in 1993.It is revised in 2004 for the first time. Compared to some relevant state laws and regulations, it is hysteretic to the government regulatory content, form and the time, no matter about the fast development of urbanization formulated time compared to the Harbin municipal solid waste management regulations. After 2009, government regulations and normative documents conditions improved.

\section{HARBIN MUNICIPAL SOLID WASTE} MANAGEMENT PROBLEMS AND THEIR REASONS

\section{A. Management Issues}

There are four aspects about the disadvantages of the current domestic waste management system, such as the management subject, management structure, management regulations, and the functions of the government:

1) The main body of waste management is not obvious, and scattered garbage management functions can't concentrate: At present, the main body of is Harbin waste management mainly concentrate tothe government .Government market-oriented reform has been established under the condition of market management and waste disposal industry. Environmental health of the government office responsible for municipal solid waste planning, policy making and management rules. City administration consists of the operations of a law enforcement agency which is responsible for monitoring sites. City environmental protection bureau is responsible for landfill environment evaluation. City bureau of finance in accordance with the relevant contract for landfill enterprise subsidies each year. In fact, in the garbage management, responsibility, right, and the relationship are divided. The government has no detailed specification for corporate and personal responsibility. 
TABLE I . HARBin MUNICIPAL SOLID WASTE MANAGEMENT'S INTERRELATED INSTRUMENT OF LEGAL DOCUMENT

\begin{tabular}{|c|c|c|c|}
\hline Nature & Time & Name & Department \\
\hline Law & 2004 & Prevention Law of Solid Waste Pollution in the People's Republic of China & National People's Congress \\
\hline $\begin{array}{l}\text { Administr } \\
\text { ative } \\
\text { regulations } \\
\text {, ministries } \\
\text { regulations }\end{array}$ & $\begin{array}{l}1992 \\
1993 \\
2005\end{array}$ & $\begin{array}{l}\text { City appearance and environmental sanitation regulations } \\
\text { Municipal management approach of waste construction }\end{array}$ & $\begin{array}{l}\text { State council } \\
\text { Ministry of Construction } \\
\text { Ministry of Construction }\end{array}$ \\
\hline $\begin{array}{l}\text { Local } \\
\text { laws and } \\
\text { regulations }\end{array}$ & 2007 & $\begin{array}{l}\text { Harbin City Appearance and Environmental Sanitation Management } \\
\text { Regulations }\end{array}$ & $\begin{array}{l}\text { Heilongjiang Provincial } \\
\text { People's Congress } \\
\text { Harbin Municipal People's } \\
\text { Congress }\end{array}$ \\
\hline \multirow{5}{*}{$\begin{array}{l}\text { Local } \\
\text { governmen } \\
\text { t } \\
\text { regulations }\end{array}$} & 2012 & $\begin{array}{l}\text { The implementation of the views of the Heilongjiang Provincial } \\
\text { People's Government on Further Strengthening the work of municipal } \\
\text { solid waste disposal }\end{array}$ & $\begin{array}{l}\text { Heilongjiang provincial } \\
\text { government }\end{array}$ \\
\hline & 2010 & Approach construction waste management in Harbin city & $\begin{array}{l}\text { Harbin } \\
\text { Government }\end{array}$ \\
\hline & 2000 & Environmental integrated management approach in Harbin urban & $\begin{array}{l}\text { Harbin } \\
\text { Government }\end{array}$ \\
\hline & 2009 & $\begin{array}{l}\text { Market-oriented reform's program on the sanitation job of propulsion in } \\
\text { Harbin }\end{array}$ & $\begin{array}{l}\text { Harbin Municipal Urban } \\
\text { Management Bureau }\end{array}$ \\
\hline & 2009 & $\begin{array}{l}\text { Management measures of Harbin City's sanitation, landscaping, road and } \\
\text { bridge maintenance's fund supervision and " }\end{array}$ & $\begin{array}{l}\text { Harbin Municipal Urban } \\
\text { Management } \\
\text { Finance Bureau, Audit } \\
\text { Bureau }\end{array}$ \\
\hline
\end{tabular}

Note: It's according to the National Office of Legislative Affairs and Harbin Office of Legislative Affairs.

2) Lack of waste management government regulations: In reality, the administrative department of the mostly adopted specific processing way do not have a specific law as the basis for the criterion. Second, most of the rules and regulations issued by "file" form, it can't run into the orbit of legal system, so authority is not guaranteed. And urban waste management are in urgent need of law serious lag, but the original government regulations revision cannot meet the need of urban development.

3) The management system is backward: Harbin city administration bureau is responsible for formulating the city's life garbage management detailed rules, and living garbage collection by the functional departments in charge of each area, fiscal department is responsible for special funds .As a result, effective implementation of waste management and waste services are both within the system. Current waste management system is still largely a continuation of planned economy, for effective management of garbage, and promoting the recycling of the waste harmless methods application ability, the waste management system has done a lot of obstacles. In addition to the administrative commands or government subsidies, Garbage processor has no economic interest drive, it can't encourage domestic and foreign enterprises to actively participate in the recycling of the waste harmless.

\section{B. Reasons of the Problem}

1) It's lack of waste management regulations: In the management of waste stream, our country have established the corresponding laws, regulations and management system, such as China's "environmental protection law". Prevention and treatment of urban garbage has made the comprehensive regulation and control of environmental pollution and it is also the basis to strengthen the management of urban refuse in our country. The state council also issued "regulations on the administration of city appearance and environmental sanitation city. The ministry of construction and the national environmental protection bureau has issued some relevant regulations, standards and procedures. Harbin city has formulated and promulgated the local environmental health management regulation as the foundation and basis of urban environmental sanitation management regulations. However, because of lack of corresponding "method", the detailed rules for the implementation brought difficulties in managing. There are also many problems in the current law.

2) The management system are not unified: The pickup and dispose of the trash of our country was under the control of the ministry of construction, under the leadership of the municipal sanitation department Harbin city trash pickup by the municipal government is in charge of collecting, transporting and disposing of garbage. The management, supervision, basic operation of trash pickup disposal process is performed by one department. Many of the city's urban environmental sanitation use the implementation of "compartmentalized integration of 
block-based" city, district, street three management system. Since main fees given by the government, it formed the phenomenon that how it work depends on how much the government give. Once it caused problems, government has to undertake the due obligations, so the government is in dilemma. At the same time, because at present the city garbage collected, removed and disposed is a heavy task, big pressure, the sanitation department management of garbage is passive in transporting and disposing, as a result they failed to overall considering the reduction, recycling and reuse of municipal waste problem.

3) Inadequate investment: In a long period of time, due to the urban sewage and garbage disposal has been regarded as a public welfare undertakings, it was entitled to free services and basic policy, so its funds mainly come from state and local financial allocation. Each year Harbin has to pay more than 4700 thousand yuan for franchise dump run. In Harbin, the average annual household fees for collected waste is 31 million yuan, annual operating subsidy capital shortfall is 16 million yuan.

4) Lack of public participation and supervision: In a broader level, in our country, waste management has long been regarded as experts and government's responsibilities. Their participation is still inadequate, especially the vulnerable groups. If we can't set up the system of stake holders to participate in real, especially to ensure the participation of vulnerable groups, we can not able to ensure that waste management can really reflects the needs of users. Although the garbage fee disposal system has established, people can not understand how does the fee price. Now the implementation of price hearing system is just a result of exports, rather than the price formation process of participation, so the public is still confused.

\section{HARBIN MUNICIPAL SOLID WASTE MANAGEMENTCOUNTERMEASURE ANALYSIS}

The successful experience in developed countries in Europe and the United States on the issue of urban waste disposal that the formation and implementation of municipal waste management and integrated processing thinking. Embodied in the policy system and management is mostly direct performanced in commonly practiced of classified collection and waste discharge fee system, and it is committed to reducing emissions from the sources, resources recycling and sanitary landfill treatment.

\section{A. To Strengthen the Management of Municipal Waste Legislation Guidance and Policy Measures}

File in the current legal norms are lack of thinking the Northern's own characteristics that they have long winter and short summer, in the garbage collection - processing has its own characteristics. They should according to the Harbin city urbanization, population and total living garbage data, in the "polluter pays" principle, make the government regulations and normative documents to formulate the corresponding government regulations.

\section{B. The Establishment of A New Urban Waste Management System}

Waste management has long been regarded as a social public welfare undertakings by the government and sanitation department as supervision management and execution unit, is the unity of government and enterprises. New urban waste management system should be built in a multiple management mode that citizens, enterprises and other social groups assist and the government as the leading role.

1) Promote the garbage sorting: The important measure to promote domestic waste reduction of municipal is to solid waste classified collection, and setting up the classified collection containers and recycling facilities. In order to achieve the target, we need to develop a series of management system, including the living garbage meterage system, plastic bottles the deposit system, packaging container reuse system, and so on.

2) Speed up the city sanitation department management system: Through Sanitation reforming, policy makers, corporate events, and supervision of law enforcement functions can be divided.What's more, combination of separating waste collection and recycling of waste materials can be done, and we can gradually achieve waste classified collection and recycle of enterprise operation, and setting up urban waste management company.

3) Encourage public to participate in waste management and supervision: Harbin government should encourage relevant social groups to supervise the whole process of urban garbage items management .It also should inform the related enterprises in the public network and use the public platform to popularize knowledge of related technologies in order to let the public and the news media play a role, so that the living garbage management office can be within social supervision.

\section{Establish a Mechanism for the Diversified Urban Garbage Project Investment}

1) Marketization of urban environmental infrastructure construction and operations is the basic system guarantee to improve the investment efficiency: And it is also an important financing function concurrently. Market-oriented approach to overcome the government-build and government-run system defects. And it also attracts private enterprises to participate, and brings market competition mechanism to finance the social capital. As a result, it improves the efficiency of municipal solid waste infrastructure and operations management.

2) Encourage social capital to participate in the construction and operation of the garbage disposal facilities: Urban waste disposal market-oriented in the field need to be further deepened. 


\section{V.CONCLUSION}

Based on the change of government function, under the background of circular economy and sustainable development ,this paper relocate government's role of city government management, build new urban management pattern in China to provide theoretical support and policy suggestions.

\section{REFERENCES}

[1] LiHongXing,LiHongjun,Analysis on the effect of agricultural tax sub sidies on the agriculture's business performance,Taxation Research , 2012, 9, pp.17-18(in Chinese).

[2] MengChu, JinZhiying, Wang Yingsen, Garbage production forecast in China,The Environmental Protection Science , 2003,12,pp. 21-24(in Chinese).

[3] Xiao Ling, Management mode of Chinese urban life waste, Arid Land Resources and Environment 2003, 5, pp65-69(in Chinese).

[4] Wang Jianming, Controls of municipal solid waste policies, Urban problems, 2008 ,8,pp.68-74(in Chinese).

[5] Peng Xuya, Management model and construction of sustainable municipal solid waste, China Population, Resources and Env ${ }^{1}$ ironment, 2002, 5, pp.146-148(in Chinese). 